\title{
FROM THE NAPOLEONIC DOMINATION UNTIL ITALIAN UNITY: LEGAL RESTRICTIONS AND INNOVATIONS FOR THE JEWISH COMMUNITY OF MONDOVÌ
}

\author{
DALLA DOMINAZIONE NAPOLEONICA ALL'UNITÀ D'ITALIA: \\ LIMITI E INNOVAZIONI PER LA COMUNITÀ EBRAICA DI MONDOVÌ
}

\author{
Ida Ferrero \\ Università degli Studi di Torino
}

\begin{abstract}
English: The documents conserved in the Terracini Jewish Archive of Turin allow the reader to examine the application of the legislation concerning Jewish communities during the period of time starting from the Napoleonic domination until the Italian unity. My research focuses in particular on the notarial deeds and judicial documents relating to the property of the synagogue and the cemetery of the Jewish community of Mondovi. Under the rule of France the Jewish people living in Piedmont were allowed to become real estate owners and the plots of land where the Jewish cemetery was located and the house that hosted the synagogue in Mondovì were allotted to the Jewish community. During the Restoration, the ban to become real estate property was introduced again. Even if the Jewish people of Mondovi had bought from its owner the house of the synagogue and they had obtained from the French administration the property of the plots of land of the cemetery, they were not anymore recognized as owners. After the emancipation of the Jewish population and the Italian unity, the Jewish community of Mondovi claimed its rights on those real estate properties: my essay would focus on the exam of the archive documents that show how the legislation concerning real estate property for Jewish people was applied over time.
\end{abstract}

Keywords: Jewish Community; Mondovì real estate property; Terracini Jewish Archive of Turin; Napoleonic domination; Italian unity

Abstract Italiano: I documenti conservati presso I'Archivio Ebraico Terracini testimoniano l'evoluzione nel tempo dell'applicazione della legislazione che riguardava la vita delle comunità ebraiche. II contributo si concentra in particolare sullo studio dei documenti notarili e processuali relativi alla proprietà della sinagoga e del cimitero ebraico nel periodo che va dalla dominazione napoleonica all'unità d'Italia. Durante il periodo napoleonico, agli ebrei residenti nei territori controllati dai francesi venne applicata la legislazione francese che aveva permesso loro di divenire proprietari immobiliari. Per questa ragione, alla Università israelitica di Mondovì fu attribuita la proprietà della parte di immobile che ospitava la sinagoga e del terreno adibito a cimitero israelitico. Dopo la Restaurazione, però, venne reintrodotto il divieto di accesso alla proprietà immobiliare per gli ebrei

* Italian Review of Legal History, 7 (2021), n. 6, pagg. 173-198

* https://riviste.unimi.it/index.php/irlh/index

* ISSN 2464-8914 - DOI 10.54103/2464-8914/16888. Articolo pubblicato sotto Licenza CC-BY. 
del Regno di Sardegna. Per questa ragione, sebbene la Comunità avesse comprato dal proprietario l'edificio della Sinagoga e avesse ottenuto dall'amministrazione francese la proprietà del terreno del cimitero, non vennero più considerati come proprietari. Dopo l'emancipazione ebraica del 1848 e con l'unità italiana, la comunità ebraica monregalese rivendicò i suoi diritti di proprietà su tali beni immobili: il mio studio mira a mostrare, attraverso l'analisi dei documenti archivistici, l'evoluzione nel tempo dell'applicazione delle regole relative all'accesso alla proprietà immobiliare per la comunità ebraica monregalese.

Parole chiave: Comunità ebraica; Mondovì; Proprietà immobiliare; Archivio Ebraico Terracini; Dominio napoleonico; Unità d'Italia

Table of contents: 1 . Introduction. -2 . The documents concerning the property of the Synagogue of Mondovì. -3 . The dispute regarding the property of the plots of land of the Jewish cemetery of the community of Mondovì. -4 . Documentary appendix.

\section{Introduction}

The Jewish communities living in the Italian Peninsula have often been subject to limits to the access to real estate property. This limit was based on religious reasons that also justified the other discriminatory rules against Jewish people The reasoning explaining this choice is evident in pope Paolo IV Carafa's words dating back to the XVI century, as he affirmed in that it seemed illogical that Jewish people, neglected and condemned to eternal slavery by God, could require to be owners instead of being subjects ${ }^{1}$.This, in addition to the will to isolate Jewish communities from the rest of the society and to limit their economic growth, led to legislation banning Jewish people in the Italian Peninsula to be real estate owners. For these reasons in 1555 the pope Paolo IV issued a decree, Cum nimis absurdum, that imposed to the Roman Jewish population to live in a restricted area, the ghetto, and prevented them from being real estate owners ${ }^{2}$. Due to these limits, it often happened that the owners of the immovable properties rented by Jewish people abused of their rights and increased the amount of the rent or expelled their tenants from their houses ${ }^{3}$. This situation created social and economic problems, so the pope Pio IV issued another decree, the Dudum ${ }^{4}$, that imposed the prohibition to force out the Jewish tenants from their houses

\footnotetext{
${ }^{1}$ Laras, 1968, p. 32, «sembrando troppo assurdo e sconveniente che i giudei condannati da Dio alla schiavitù eterna» could require «dominio invece che sottomissione».

${ }^{2}$ Raccolta di costituzioni, 1877, p. 88; Baccelli, 1892, p. 712, who stated that the Jewish population living in Rome could not have more than one synagogue and «ne bona immobilia possidere».

3 Baccelli, 1892, p. 712, who stated that the owners of the apartments rented by Jewish people "sapendo che egli non potessero abitare che quelle, gli angariavano».

${ }^{4}$ The text of the constitution of the Pope is published in Raccolta di costituzioni, 1877,
} 
and to increase the rent.

This legislation was in force only in the State of the Church, but this model was followed also by the other governments of the Italian peninsula, including the one of the Duchy of Savoy. Starting from the Statutes granted by Amedeo $\mathrm{VII}^{5}$ in 1430, the first legislative tool that aimed at implementing a centralized ruling of the lives of the Jewish people, the provision that prohibited to the Jewish population to be real estate owners had always been included both in the state legislation and in the local one. In fact, also the condotte -which were the contracts regulating the rights and duties of the single Jewish community with the central government or with the local authority - usually included a rule that prohibited to Jewish people to access to real estate property ${ }^{6}$. Another reason for the exclusion from real estate property derived from the fact that the legal condition of the Jewish population was assimilated to the one of foreign people: the strong link between real estate property and the belonging to the state community determined the exclusion of both foreign and Jewish people from those kinds of rights $^{7}$. The type of legislative tool selected to regulate their rights and duties and the relationship with the other citizens was also a consequence of that kind of approach. In fact, as I said above, the condotte had the form of a contract and lasted for a limited period of time (usually ten years) ${ }^{8}$. Even if they have always been renewed, their limited term offered to the administration a double benefit. On the one hand, they reserved the right to expel the Jewish citizen and, therefore, to impose the limits and duties without any opposition; on the other hand, every new condotta included the annual payment of a tax and entailed the payment of a sum of money at the time of the signature of the agreement ${ }^{9}$.

It is important to underline that this legislation was accompanied by other rules that aimed at ensuring the worthwhile exercise of the commercial activities held by Jewish people ${ }^{10}$. The significance of these economic activities is confirmed by

p. 1.

${ }^{5}$ Caesar, 2019, p. 372.

${ }^{6}$ Duboin, 1825, p. 422: this kind of rules had a long-lasting effect as, still in 1724, the Condotta signed that year stated that Jewish people could not claim to be real estate owners, «mai possano pretendere di ritenere beni stabili»

${ }^{7}$ Vigna-Aliberti, 1848, p. 162, where they stated that property was «fonte d'ogni civico diritto [the source of every civic right» and so, being excluded from it, they were also isolated from the other citizens. Also Montalcini, 1884, p.80, stated that «essi [the Jewish population living in the Duchy] non erano tenuti nello Stato se non come stranieri, e come a stranieri si concedeva il permesso cli abitar nello Stato, il che è provato dagli stessi peculiari privilegi di che essi godevano»

${ }^{8}$ Vigna-Aliberti, 1848, p. 18, where the authors affirmed that «I Giudei essendo, come più volte avemmo ad osservare, considerati stranieri, queste leggi non potevansi altrimenti considerare che come patti i quali fissavano i loro diritti ed i loro rapporti»

${ }^{9}$ Duboin , 1825, p. 305.

${ }^{10}$ Montalcini, p. 79 who affirmed that the «nelle loro mani era buona parte del commer- 
the right that Jewish people had to receive immovable property for the payment of a debt or to keep it as a guarantee for a loan, even if this right was complemented by the duty to sell the immovable goods as soon as possible ${ }^{11}$.

The limits to the access to property lasted for centuries. In the eighteenth century the Royal Constitutions issued by Vittorio Amedeo II not only maintained but also tightened the general rules concerning the lives of the Jewish population and the ones concerning the right to gain access to private property. The editions dating back to 1729 and 1770 included the duty to sell immediately the real estate property received as a payment for a debt ${ }^{12}$, with the sanction of its confiscation if the rule had not been applied ${ }^{13}$.

A complete change of the lives of the Jewish communities in the Kingdom of Sardinia took place during the period of the French domination, when the legislation concerning the French Jewish population was applied also to the Piedmont's Jewish communities. Already in 1790 , a project was presented to the French constitutional assembly that aimed to recognise the citizenship also to the people living in France who were born from foreign parents. It was also the case of Jewish people as they were assimilated to foreigners ${ }^{14}$.

After the project's presentation, a decree dating back to 27th September 1791, issued on the 15th of November, affirmed that the national assembly had stated that the citizenship would have been attributed to every person living in France who would have respected the constitution and would have taken the 'civic oath $^{\prime 15}$. In this way, the Jewish citizens were assimilated to the other ones and

cio dello stato»

${ }^{11}$ Duboin, 1825, p. 300. The legislation included the right to "aver, e ritener, e in pagamento togliere, ovvero per via di ragione farseli deliberare, ed essi goder e posseder e farne cosa propria».

${ }^{12}$ Vigna-Aliberti, 1848, p. 106, where they stated that «se in occasione di qualche esecuzione sopra i beni del debitore o nel caso dell'Auth. Hoch nisi debitor. Cod. de solution saranno costretti a prenderne in pagamento, vogliamo che passato il termine del riscatto siano tenuti ad alienarli a persone capaci un anno dopo, sotto la medesima pena [la confisca]».

${ }^{13}$ Artom, 1950, p. 28; Mantelli, 1843, p. 129; RR.CC. 1729, titolo VIII capo III, art. I, pp. 32-33.

${ }^{14}$ Merlin, 1836, p. 130. The project aimed to attribute the citizenship to those: «nati fuori del regno da genitori stranieri, erano stabiliti in Francia, se però vi avessero un domicilio continuato da cinque anni, e che vi avessero o acquistati immobili, o sposato una francese, o formato uno stabilimento di commercio, o ricevuto in qualche città lettere di cittadinanza».

${ }^{15}$ Lazare, 2006, p. 148; Di Rienzo, 1994, pp. 87-105. The decree stated that all the previous limits concerning Jewish people were abolished, for the individuals who would have taken the 'civic oath' : «Rivoca tutte le approvazioni, le riserve ed eccezioni inserite ne precedenti decreti a riguardo degl'individui Ebrei che daranno il giuramento civico, il quale sarà riguardato come una rinunzia a tutt'i privilegi e le eccezioni introdotte precedentemente in loro favore» 
gained access to the right to own private property ${ }^{16}$. The new status of the Jewish population was also extended between 1796 and 1799 to the Jewish population living in the parts of the Italian peninsula invaded by Napoleon ${ }^{17}$.

Napoleon also decided to gather the most important representatives of the Jewish communities with the aim to discuss the most important areas concerning their lives and their contribution as members of the "corpo della Nazione» ${ }^{18}$. The following year a 'Great Sanhedrin' was summoned and involved the most important Jewish religious authorities: 19 members of the Sanhedrin (of 71 total members) came from the communities of the Italian peninsula. In the opinion of some authors, the wish of the French government was the one to obtain a reply from the 'Great Sanhedrin' that stated that, due to religious features, the Jewish population could not belong to the state community ${ }^{19}$. In reality, the decree issued by the 'Great Sanhedrin' on the 4th of February 1807 stated the opposite and invitedJewish people to "acquistare beni stabili anche per affezionarsi vieppiù alla patria» ${ }^{20}$. As a matter of fact, it affirmed that

invite en outre, le Grand Sanhédrin, les Israelites de deux Etats de France et d'Italie, d'acquérir les propriétés foncières, comme un moyen de s'attacher davantage à son patrie, de renoncer a des occupations qui rendent les hommes odieux et méprisables aux yeux de leur concitoyens ${ }^{21}$

The introduction of the French legislation completely changed the lives of the Jewish communities of the Kingdom of Sardinia. Before considering the innovations that took place because of the right to be real estate owners, it is important to underline that the Jewish people had enjoyed - starting from the XVI century - the opportunity to be holder of the ius cazacà. It was a particular kind of right that provided Jewish people living in the Italian peninsula with a legal

\footnotetext{
${ }^{16}$ Cattaneo, 1860, p.11, where the author affirmed that «l'ebreo nato o naturato in Francia non fu più straniero e venne compreso nella generale appellazione e qualificazione di cittadino»; Levi, 1952, p. 414, Per circa due decenni, sotto il dominio francese, gli Ebrei residenti nel territorio del Regno Sardo avevano potuto liberamente commerciare, acquistare beni immobili, esercitare arti e mestieri, frequentare le università far parte dell'esercito, assumere cariche pubbliche, abitare in qualsiasi luogo, viaggiare di giorno e di notte, senza permessi del Vicario e senza segno giallo

17 Della Peruta, 1997, pp. 1135-1136. For what concerned the Kingdom of Sardinia, the new legislation had already been applied already in 1792 for the Jewish community of Nice due to the occupation of the city by the army of the grande nation.

${ }^{18}$ Tama, 1807; Capefigue, 1842, p. 16, where the author stated that «si trattava di far decidere le quistioni che si rannodavano collo stato civile degli ebrei e colla loro attitudine ad appartenere al corpo sociale, onde metterli in relazione con le leggi e il codice del paese».

${ }^{19}$ Bachi, 1931, p. 252.

${ }^{20}$ Mantelli, 1843, p. 130

${ }^{21}$ Tama, 1807, p. 107.
} 
framework to use real estate property. It was created in the XVI century and combined elements of different legal tools (such as lease, perpetual lease, property) to answer to the commercial and housing needs of the Jewish communities. It was a lease right that implied the payment of a rent each year. However, it was possible to hand it over, to transfer it to the heirs and it could be the content of a dowry. Because of these peculiarities, it was a sui generis right that had some traits of property and some of the traditional lease ${ }^{22}$. The attribution of this kind of right offered to the Jewish people the chance to have a stable use of some buildings and the public control on this kind of lease prevented Christian owners from speculating on it. Its importance depended on the fact that Jewish people were forbidden from being real estate owners, and therefore needed a legal framework such as the of the ius cazacà to have access to property. Over time, the content of the right of the owner under the ius cazacà reduced to the simple collection of the rent. Even if the ius cazacà had been an important tool in order to answer to the social and economic needs of the Piedmont's Jewish communities, the introduction of the right to be real estate owners changed their status and the community life.

\section{The documents concerning the property of the Synagogue of Mondovi}

An interesting example of the change occurred due to the French legislation is the one of the Jewish Community of Mondovi where, because of the new rules introduced by the French government, the property of the plots of land where the Jewish cemetery was located and the house that hosted the Synagogue in Mondovì were allotted to the Jewish community. For what concerns the Synagogue, the owner of the house, Jean Louis Bonello, sold to the Jewish community the third floor of his house that had already been rented by the Jewish community and used as synagogue

vend à profit de l'université des juifs établie en la présente ville de Mondovì, pour elle stipulant l'ici présent sieur Samuel Salvador Momigliano fils au défunt Elias Abraham, membre de la même et demeurant en cette ville d'après l'autorité qui

\footnotetext{
${ }^{22}$ Raccolta di costituzioni, 1877, p. 84, where the legal scholar, lawyer and politician Giovanni Battista Cassinis gave his legal counsel about a dispute concerning the Jewish community of Ancona and affirmed that «con nome più proprio chiameremo direttario, una prestazione annua, in ricognizione del dominio diretto, se inoltre il ius Cazacà praeseferebat quandam capacitate dominii improprii, ed attribuiva specialissimi effetti, eminentemente utili al conduttore - o utilista - quali erano le facoltà di dedurre in contratto quel diritto, di venderlo, di cederlo, di costituirlo in dote, di assoggettarlo ad ipoteca». Another authoritative scholar, Pasquale Stanislao Mancini, also defined the ius cazacà as "Questa specie di diritto immobiliare che la inesorabile abrogata legislazione unicamente permetteva agli ebrei di acquistare e possedere», Raccolta di costituzioni, 1877, p. 87.
} 
vient de lui être conférée par la dite université en vertu de l'acte de procuration de treize présent mois d'janvier passé par devant au notaire duement enregistré, et qui sera annexé au présent acte. le troisième étage ou soit dernier de la maison par le même sieur Bonello, possédée en cette ville, incorporée parmi les autres habites par la juiverie, composé d'une grande chambre servant actuellement de synagogue, deux autres petites chambres contiguës ${ }^{23}$

The sale of that part of the house was recorded by a notary with the form of a «vente perpetuelle». That type of sale did not entail the immediate payment of the entire amount of money but a yearly payment of $\%$ of it. In the case concerning the Jewish community of Mondovì, the price of that part of the house was of five hundred marcs and the Jewish community had to pay yearly 25 marcs (5\% of the global amount of money). Every member of the Jewish community was jointly liable for that payment and the Jewish community could also decide at any time to give to the previous owner or his heirs the entire amount of money and, so, to stop the yearly payment

celle vente moyennant le prix et somme de cinq cent francs, que selon l'intelligence précédée au présent sera constituée en vente perpétuelle, et ainsi sera tenue la dicte université et pour elle les membres que la composent, et solidairement l'un pour l'autre, au payement des intérêts annuel du dit capitale réglée, et convenu en tant du cinq pour cent, laquelle vente sera rachetable à plaisir de la dicte université ${ }^{24}$

On the other hand, the Jewish community of Mondovì had to raise a mortgage on its properties with the aim to guarantee the payment to Jean Louis Bonello and his heirs.

After the Restoration the ban to access real estate property was introduced again: the royal decree issued by Vittorio Emanuele I on the 21st of May $1814^{25}$ stated that Jewish people could no longer be real estate owners and had the duty to sell within five years the goods they had purchased.

For what concerns the Synagogue of Mondovì, the fact that it had been sold as 'vente perpetuelle' made possible to transform the purchase - and so the real estate property - in a censo perpetuo. It had some common features with the ius cazacà: in fact, also in this case the formal title of real estate property was still in the hands of the Christian owner [in this case Tommaso Bonelli, the son of Jean

${ }^{23}$ The document of the Vente par le sieur Jean Louis Bonello à profit de l'Université des juifs etabli à Mondovì is conserved at the Jewish Archive Terracini of Turin [from now named as AET], (Comunità ebraica di Mondovì, Patrimonio, beni immobili. Sinagoga-1807/1913, I.2.2.1, first page).

${ }^{24}$ AET, Comunità ebraica di Mondovì, Patrimonio, beni immobili. Sinagoga-1807/1913,

I.2.2.1, second page.

${ }^{25}$ Baccelli, 1892, p. 173 
Louis Bonelli26] but the continuing enjoyment of the contents of the right was attributed to the Jewish community on payment of a yearly rent. In this way, on the one hand it was possible to follow the rule that prohibited to Jewish people to be real estate owners, on the other hand, it offered the opportunity to answer to the housing and commercial needs of the Jewish population ${ }^{27}$. Even if the ban to access real estate property was repeated with the Regie Patenti issued by King Carlo Felice dating back to 15th February 1822, that legislation included an important change regarding the opportunity for Jewish people to buy and to keep the dividend warrants of public debt ${ }^{28}$.

In fact, the need to protect the commercial and business activities held by the Jewish population implied some limits to the ban to access to real estate property- such as the one mentioned - and imposed the grant of a respite to the duty to sell the goods they had bought during the French occupation. As Giorgina Levi affirmed, this kind of approach prevailed on the strict respect of the rules depending on canon law

In tutto ciò appaiono evidenti due fatti: che nel governo era spesso più forte la preoccupazione di non ledere gli interessi delle migliori aziende ebraiche che di apparire innanzi tutto zelante osservatore del diritto canonico; e che tale situazione confusa, incerta e di compromesso non avrebbe potuto durare molto a lungo e che quindi l'unica soluzione doveva essere la emancipazione completa ${ }^{29}$

For what concerns the Synagogue of Mondovì, the mortgage was renewed in 1823, 1838 and 1853 as it results from the document conserved the Jewish Archive Terracini of Turin ${ }^{30}$. Even if, after the emancipation that took place in 1848,

${ }^{26}$ The owner was called with the surname Bonello in the sale document dating back to 1807 and in some. In the other documents the owner and his son are called with the surname Bonelli.

${ }^{27}$ The importance of their contribution to the economic system of the country is underlin in Levi, 1952, p. 406, where the author affirmed that «Gli Ebrei del Regno di Sardegna sono alleati dei liberali (come dimostra la collaborazione degli Ebrei ai moti patriottici del 1821 e degli anni successivi, non ancora sufficientemente studiata), non solo per una costante e quasi innata sete di libertà dell'individuo ebreo da secoli oppresso, ma soprattutto perché il piccolo gruppo di Ebrei piemontesi (seimila anime circa) é diventato una parte attiva della borghesia in ascesa, si é inserito nei rapporti di produzione di tipo borghese, detiene e sa maneggiare notevoli capitali, esercita il commercio, crea e dirige manifatture di grande importanza per il paese».

${ }^{28}$ Gazzetta Piemontese, 1822, p. 126, «Dichiariamo, che non si intenderà vietato agli Ebrei di acquistare, e ritenere non solo le cedole del Debito pubblico redimibile, ma eziandio quelle del Debito pubblico perpetuo».

${ }^{29}$ Levi, 1952, p. 425.

${ }^{30}$ The documents concerning the mortgage are the following: AET, Comunità ebraica di Mondovì, Patrimonio, beni immobili, Sinagoga-1807/1913, Nota d'iscrizione di censo perpetuo 1823, I. 2.2.2; AET, Comunità ebraica di Mondovì, Patrimonio, beni immobili. Sinagoga-1807/1913, Iscrizione ipotecaria a rinnovazione di quella venti quattro ottobre mille 
the Jewish people living in the Kingdom of Sardinia had the right to be real estate owners, the Jewish community of Mondovi continued for some years to pay the yearly rent due to Bonelli and his heirs because of the censo perpetuo. Only in 1869 the Administration council of the Jewish community of Mondovi chose to redeem the censo perpetuo paying the due amount of money. The reasons for this decision were the following:

Considerando

Che un censo annuo sovra un Sacro edificio mentre è cosa di poco decoro porta una spesa continua che è bene eliminare dai bilanci e l'edificio stesso non rimanendo mai di assoluta proprietà della Comunione,

Considerando che il creditore deve a nostro vantaggio la somma di L. 50 ove gli venga pagato il debito per intiero

Considerando che senza aggravare per il momento i contribuenti, una delle nostre confraternite religiose può prelevare dai suoi fondi la suddetta somma di L. 450 rimborsabile in tre rate coi dovuti interessi

Si delibera all'unanimità

Di prelevare ad una confraternita la somma di L. 450 da pagarsi agli eredi del defunto Bonelli cancellando così il debito contratto e nello stesso tempo il censo relativo

Di ripartire la stessa somma in tre rate dal L. 150 l'una da aggiungersi nei bilanci degli anni $1870-71$ e $72^{31}$

The Council had the opinion that real estate property better suited the right that the Jewish community had on a sacred building such as the one of their Synagogue than the censo perpetuo. The Jewish community used the money that formed part of the wealth of the Jewish charity institution of the town to pay for the building.After this agreement, the heir of the first owner - Matteo Bonelli had the duty to raise a mortgage to guarantee the new owner from every possible claim ${ }^{32}$. He decided to raise this mortgage on the house he lived in and some

ottocento venti tre al vol. 38 art. 124 di censo perpetuo costituito con instrumento del quattordici gennaio mille otto cento sette, I.2.2.3; AET, Comunità ebraica di Mondovì, Patrimonio, beni immobili. Sinagoga-1807/1913, Iscrizione ipotecaria a rinnovazione della precedente tre marzo milleottocento trentotto al vol. n. 217 art. 102 e di censo perpetuo costituito con instrumento quattordici marzo mille ottocentosette rogato Bassi debitamente insinuato, I.2.2.4.

${ }^{31}$ AET, Comunità ebraica di Mondovì, Patrimonio, beni immobili. Sinagoga-1807/1913, affrancamento censo e acquisto, Estinzione del debito dell'oratorio, I.2.2.5.

32 The purpose of the mortgage was to guarantee to the buyer to «tener rilevata la predetta Università da qualsiasi domanda che altri potessero farle per tale censo», AET, Comunità ebraica di Mondovì, Patrimonio, beni immobili. Sinagoga-1807/1913, affrancamento censo e acquisto, Riscatto di censo perpetuo, mediante la somma di lire quattrocento cinquanta, L. 450 operato dalla Università israelitica di Mondovì, col signor Matteo Bonelli, I.2.2.6. 
fields he owned in Vicoforte, close to Mondovi ${ }^{33}$.

The documents concerning the property of the Synagogue of Mondovi show the development over time of the limits and the innovations regarding the access to real estate property for the Jewish population, starting from the Napoleonic domination up to the period after the Italian Unity. Even if the title of the right held on the building changed over time - property with a vente perpetuelle under the French domination, censo perpetuo during the Restoration and then again property in 1869 - its content had always been the same as the right to use the rooms as a Synagogue had never been questioned.

\section{The dispute regarding the property of the plots of land of the Jewish cemetery of the community of Mondovi}

A different development has marked the property of the plots of land where the Jewish cemetery of Mondovì was located. The French government decided in 1809 to attribute to the Jewish community the "possession et jouissance du terrain ${ }^{34}$ close to the town walls and the citadel that hosted the Jewish graveyard. Those plots of land had been also added in 1811 to the cadastre as belonging to the Jewish community, as the members of the community affirmed in a letter dating back to the 22 nd of December 1844 sent to the general Intendant ${ }^{35}$. It also appeared from that letter that - after the restoration - the Jewish community had reached the agreement to pay a yearly rent of 54 lire

Al repristinamento dell'attuale governo il sig. Comandante della città di Mondovì, a cui anticamente spettava la la goldita dei siti annessi ai bastioni della cittadellla, di cui fanno parte le suddette due pezze n.16565 e 16566, pretese che la Esponente gli pagasse per fitto o canone della pezza suddetta 16566, di cui si serviva ad uso di cimiterio, la somma di lire cinquantaquattro annue, che venne e viene pure ad essa annualmente corrisposta ${ }^{36}$.

${ }^{33}$ The mortgage was raised on the house of Matteo Bonelli, the kitchen garden, the lawn and some fields close to the house, "sottopone ad ipoteca speciale l'intiera sua casa coll'aja, orto, prato e campo attiguo, formante il tutto un solo appezzamento, che tiene a Vicoforte», AET, Comunità ebraica di Mondovì, Patrimonio, Beni immobili, Sinagoga-1807/1913, affrancamento censo e acquisto, Nota di iscrizione di ipoteca, 1.2.2.7.

${ }^{34}$ The decision dating back to 18th November 1809 stated that «les juifs résiliant dans la ville de Mondovì dipt. de la Stura, sont maintenant dans la possession et jouissance du terrain dépendant des fortification de cette ville et servant de cimetière conformément aux dispositions de l'article 9 du Décret Impérial du 23 mai 1809», AET, Comunità ebraica di Mondovì, Patrimonio, Beni immobili, Cimitero-1809/1914, IV.1.1.

${ }^{35}$ «Vennero anche l'anno 1811 accollonate alla esponente li suddetti stabili come ne consta da certificato come ne consta dal certificato del sig. Catastiano di Mondovì delli 20 febbraio 1844», AET, Comunità ebraica di Mondovì, Patrimonio, Beni immobili, Cimitero-1809/1914, IV.1.4, second page.

${ }^{36}$ AET, Comunità ebraica di Mondovì, Patrimonio, Beni immobili, Cimitero-1809/1914, 
In this way, even if the community was not anymore tagged as 'owner' of the pieces of land, its members could anyway enjoy the possession of the cemetery and the surrounding terrains. Reading the documents conserved at the Jewish Archive Terracinin of Turin, it seemed that the Jewish population of Mondovi also used to till those lands with the aim to grow some vegetables and to cut the grass and sell the hay. The other citizens of the town were critical of those activities, and evidence of this remains as the town surveyor Carlo Pirotti wrote a claim to the Giunta provinciale di Sanità di Mondovì [the health departmental council] affirming that the use of those plots of land could endanger public health and infringed the law

l'abuso, che da un tempo a questa parte si permette l'Università Israelitica, o chi per essa, di praticare opere di coltivazione attorno al di lei cimiterio, sito nei spalti di questa città, massime dal lato del mezzogiorno, e di recidere e vendere l'erba, che nasce nel Cimeterio stesso, cose queste che, oltre ad essere riprovate dalle leggi, sono nocive alla pubblica salute, massime la prima, pel fetore che ne esala dalle escavazioni, non trovandosi tanto più quel cimeterio alla prescritta distanza dall'abitato, lo stesso sig. Presidente, previo accertamento dato alla giunta d'avere egli stesso riconosciuta la sussistenza di tali abusi, invita gli Illustri Congregati a provvedere al riparo ${ }^{37}$

The reply of the Giunta stated that the use of the plots of land as cemetery by the Jewish community would not be put in doubt but that they prohibited to the Jewish population to till the soil, cut the grass, and burn it.

nel mentre stima per ora di non ordinare per ora variazione alcuna in quanto alla località del Cimitero degli Ebrei, ha però determinato e determina che sia immediatamente inibita l'Università Israelitica di questa città, o chi per essa, di non più permettersi, né permettere, che altri faccino opere di coltivazione attorno al di lui cimitero e nemmeno di non più recidere l'erba, che nasce nel cimitero stesso se non per abbruniarla nel luogo medesimo, e che di più sia anche ordinato all'Università stessa di dovere fra dieci giorni far togliere, per essere pure abbruniati dal luogo, gli erbaggi e legumi, che si trovano attualmente nel cimitero, che attorno d'esso, sotto comminazione, in caso di trasgressione, delle pene portate dalle leggi e regolamenti di sanità ${ }^{38}$.

Even if the Jewish community had agreed to pay the annual rent for those plots of land, its delegates claimed -in the letter dating back to the 22nd of December 1844 - that one piece of land (the one with number 16565) was not at their disposal because it was used by the commanding officer of the Department and, because of this reason, they had asked to cancel it from the land register as be-

\footnotetext{
IV.1.4, first page.

${ }^{37}$ AET, Comunità ebraica di Mondovì, Patrimonio, Beni immobili, Cimitero-1809/1914, IV.2.1, first page.

${ }^{38}$ AET, Comunità ebraica di Mondovì, Patrimonio, Beni immobili, Cimitero-1809/1914, IV.2.1, first and second page.
} 
longing to them ${ }^{39}$. Their request had been rejected by the War Ministry because its officer affirmed that the handover done by the French government of the real estate property of the Synagogue and of the plots of land was not intended as a conveyance of property but just as a permission to use those goods as they were needed as Synagogue and cemetery. So, if the piece of land n. 16565 was not used as a cemetery they did not have any title to ask for its dismissal.

non si ravvisava ammessibile la domanda dell'Esponente perché la cessione fattale dal Governo francese degli stabili in discorso, non debba intendersi fatta in titolo di proprietà, ma bensì soltanto per l'uso a cui li stabili ceduti erano destinati, cioè per cimiterio e per la scuola della Sinagoga, così che risultando che lo stabile n. 16565 ch'essa reclamano non era necessario per l'uso del cimiterio, non sussistesse la domanda per la dismessione d'essa ${ }^{40}$

Because of this reply, the representatives of the Jewish community claimed that, if they were not owners, nor possessors, neither used that piece of land, there was no reason justifying the payment of the yearly rent that they had already paid and that the continued payment in the future.

la Esponente non ha alcun domenio, né goldita, né uso, di maniera che priva come si trova di domenio e perfino di uso gratuito della proprietà si dette, non è giusto ch'esse siano sinora state e siano alla di lei colonna, e ne abbia pagato e continui a pagare le contribuzioni

Reading the documents conserved at the Jewish Archive Terracini of Turin it is possible to understand that the request of the Jewish community should have been denied as they asked, in 1852, a legal advice from a renowned scholar and lawyer Giovanni Battista Cassinis ${ }^{41}$. The choice of such an influential jurist is surely a proof of the importance of that legal dispute for the community of Mondovi. As it appears from the answer of the lawyer, the will of the Jewish community was to receive his advice about their right to assert a claim for the possession of the piece n. 16565 and if they had the right to refuse the payment of the rent in case the Jewish community managed to prove the 'immemorial possession' of those plots of land:

1) Se essa abbia diritto di rivendicare la pezza n. 16565

2)Se abbia diritto di esimersi dal pagamento di scudi 15 da lire 3 delle lire 45 per

\footnotetext{
${ }^{39}$ AET, Comunità ebraica di Mondovì, Patrimonio, Beni immobili, Cimitero-1809/1914, IV.1.4, second and third page, "cuorse pure che la esponente non trovandosi ad avere il materiale possesso della pezza 16565, la quale viene goduta dal sig. Comandante della Provincia non ostante stata come sovra ad essa ceduta, inoltrò le sue supplicazioni al Ministero di Guerra e Marineria onde gliene fosse procurata la dismessione».

${ }^{40}$ AET, Comunità ebraica di Mondovì, Patrimonio, Beni immobili, Cimitero-1809/1914, IV.1.4, third page.

${ }^{41}$ Solimano, 2003; Martone, 1978, pp. 490-494; Garizio, 1867; Sarti, 1896, p. 245; Dionisotti, 1881.
} 
essa corrisposte annualmente e prima dell'occupazione francese e dopo il 1814 al Governo in ricognizione del dominio di dette pezze ${ }^{42}$

Reading the document of Giovanni Battista Cassinis, it appears that the Jewish community used to pay before the French domination 15 scudi for the rent of the plots of land n. 16565 and n. 16566 and they enjoyed their 'immemorial possession'. They used the first piece as an access to the cemetery and the second as graveyard. The contribution stopped after the mentioned decision of the French administration

alla sopravvenienza del Governo francese l'Università israelitica di Mondovì non pagò più il mentovato canone, e colla decisione suddetta del Ministro di Finanze venne mantenuta nel possesso e godimento del terreno in discorso, ossia come ivi si legge del terreno dipendente dalle fortificazioni di Mondovì inserviente di cimitero conformemente alle disposizioni di decreto imperiale del 23 maggio $1806^{43}$

Even if no document of the French administration expressly stated that the Jewish community was the real estate owner of those plots of lands, the two elements of the possession of those pieces of land without the payment of a rent and the new legislation allowing Jewish people to be real estate owners could have induced them to believe that they were owners of the terrains of the cemetery. During the Restoration the commander officer of the town of Mondovi imposed again the payment of the rent and rented to a third person the piece of land n. 16565 that could not be used anymore by the Jewish community ${ }^{44}$. Trying to answer to the first question of his clients, Cassinis affirmed that the decision of the French Government could not be used as a proof for the right to assert a claim for the possession of the piece n. 16565. The first reason supporting his opinion was the one regarding the fact that the French decision was not included in the official collection of the laws of the government and that that kind of purchase should have been determined by a law. In addition to this, the text of the French decision seemed to focus more on the enjoyment of the piece of land as a cemetery than on its property ${ }^{45}$.

${ }^{42}$ AET, Comunità ebraica di Mondovì, Patrimonio, Beni immobili, Cimitero-1809/1914, IV. 1.7, first page.

${ }^{43}$ AET, Comunità ebraica di Mondovì, Patrimonio, Beni immobili, Cimitero-1809/1914, IV. 1.7 , second page.

${ }^{44}$ AET, Comunità ebraica di Mondovì, Patrimonio, Beni immobili, Cimitero-1809/1914, IV. 1.7, second page, «cessata l'occupazione francese il Comandante della città di Mondovì richiamò l'antica prestazione dei quindeci scudi, e di più observando, che l'Università Israelitica si servisse di una di dette pezze per cimitero, diede ad un estraneo in locazione unitamente agli spalti della cittadella la pezza descritta col numero 16565».

${ }^{45}$ AET, Comunità ebraica di Mondovì, Patrimonio, Beni immobili, Cimitero-1809/1914, IV. 1.7, fourth and fifth page.

«1) Perché quel Decreto imperiale non esiste nella raccolta ufficiale delle leggi del 
Because of these reasons, the Jewish community of Mondovi could not rely on the decision of the French government as a support to the claim of its members. Cassinis then analysed the topic of the presumed 'immemorial possession' that could have been the source of the asserted rights of the Jewish community on those plots of land. Also in this case, he affirmed that it was not easy to prove that their possession could justify the rights they claimed on those real estate goods. In fact, as the plots of land were close to the town walls and citadel, they were surely state property and so no prescription of the State rights was possible even if the Jewish community had an 'immemorial possession' of its real estate goods ${ }^{46}$. On the other hand, Cassinis stated that the town walls and the citadel were no longer "piazze di guerra» as they did not have any defensive function anymore and so, even if they were state property, they could be purchased and thus be subject to positive prescription, «sono dichiarati di proprietà demaniale, ma alienabili, indi ancora prescrittibili». In addition to this the continuing payment of the rent could support the claim of the Jewish community, confirming the mutual consent of the parties regarding the possession of the Jewish cemetery ${ }^{47}$.

\section{Governo.}

2) Perché quand'anche esistesse diffatti, e si potesse in alcuna parte rinvenire, e se ne volessero avere gli effetti d'una vera alienazione a favore dell'Università, esso non sarebbe stato a ciò efficace, imperocché non si sarebbe potuto tale alienazione operare tranne per legge.

3) Perché stando ai termini della decisione, che dovette necessariamente essere conforme al Decreto, vi si vedrebbe piuttosto accordato il godimento pel fine ivi indicato cioè di uso di cimitero, anziché fatta una vera alienazione»

${ }^{46}$ AET, Comunità ebraica di Mondovì, Patrimonio, Beni immobili, Cimitero-1809/1914, IV. 1.7, tenth and eleventh page, «quel terreno era di spettanza dello Stato; ora siccome anteriormente ai codici francesi, e patrio le proprietà demaniali erano presso di noi imprescrittibili, come il sono anche secondo i codici stessi i diritti demaniali contemplati nel libro $2^{\circ}$ cap. $3^{\circ}$ titolo $1^{\circ}$ del codice patrio, tra cui le mura, le fossa, i bastioni delle piazze ed $\mathrm{i}$ terreni delle fortificazioni, che non sono piazze di guerra, di qui potrebbe arguirsi che quel possesso quand'anche avesse di fatto esistito non fosse attendibile per la prescrizione».

${ }^{47}$ AET, Comunità ebraica di Mondovì, Patrimonio, Beni immobili, Cimitero-1809/1914, IV. 1.7, eleventh and twelfth page "Ora siccome il possesso dell'Università israelitica era accompagnato dal pagamento di un canone, aveva perciò un'origine consensuale. Egli era, e fu tale insomma da costituire il fondamento d'un diritto irrevocabile, semprechè si pagasse il canone consueto.

$\mathrm{Ne}$ fa in contrario, come ben si comprende, che pendente il governo francese non siasi pagato il canone; ciò non tolse l'antica origine, ciò non distrusse quei diritti ingeniti ad un possesso legittimo che già l'Università israelitica ne aveva acquistati.

Col 1814 essendosi poi di nuovo ripristinato il Canone, l'Università israelitica venne reintegrata, se pure ve ne fosse stato il bisogno in tutta quella condizione di diritto, e di fatto, in cui si trovava anteriormente all'occupazione francese». 
For what concerned the plot n. 16565, in the opinion of Cassinis a possible problem could derive from the fact that the Jewish community did not enjoy the possession of that terrain anymore:

più grave di ogni altra vi è la difficoltà che sorge da che l'Università israelitica non possegga più la pezza 16565 .

Nel che vuolsi distinguere se da più di 30 anni essa abbia cessato di possederla ovvero da minor tempo.

Avvegnachè nel primo caso essa per difetto così di titolo come di possesso non avrebbe estremo veruno per rivendicarla, le gioverebbe nel secondo caso l'antico possesso, comechè non distrutto ancora da possesso contrario che ne abbia l'azione di rivendicazione ${ }^{48}$

Cassinis also added that, if the Jewish community should have continued to be excluded from the plot $\mathrm{n}$. 16565, it could be used as a good reason with the aim to obtain a reduction of the amount of the rent ${ }^{49}$. In conclusion, the lawyer affirmed that

Dietro a tutte le cose sin qui dette conchiudo:

Che l'Università ha diritto ad entrambe le pezze di terreno summentovate, ove ella sia in grado di giustificare un possesso immemoriale

Che al possesso, e non alla decisione ministeriale, e al decreto imperiale suddetti ella debbe fondare il suo assunto Che non avrebbe il diritto di rivendicare la pezza n. 16565 ove da più di anni 30 ella abbia cessato di possederla Che non potrebbe dispensarsi dal pagamento del canone Che ove ella non potesse più conseguire la pezza $\mathrm{n}$. 16565 ella avrebbe diritto ad una proporzionata diminuzione del canone ${ }^{50}$.

Unfortunately, no other document present at the Jewish Archive Terracini could show if the community of Mondovì has managed to prove the 'immemorial possession' of those plots of land. Even if they probably did not manage to reach their purpose, I believe that the documents and notarial deeds concerning both the Synagogue and the cemetery show to the reader the existence of a lively community that, notwithstanding the legislative limits, had the cultural and economic tools needed to safeguard their interests and to interact with the governmental and administrative authorities of the State. In conclusion, the changes of the legislation concerning the right to have access to real estate property for the

\footnotetext{
${ }^{48}$ AET, Comunità ebraica di Mondovì, Patrimonio, Beni immobili, Cimitero-1809/1914, IV. 1.7, thirteenth page.

${ }^{49}$ AET, Comunità ebraica di Mondovì, Patrimonio, Beni immobili, Cimitero-1809/1914, IV. 1.7, fourteenth page.

${ }^{50}$ AET, Comunità ebraica di Mondovì, Patrimonio, Beni immobili, Cimitero-1809/1914, IV. 1.7, fourteenth and fifteenth page.
} 
Jewish population, starting from the innovations introduced by the French government up to the Italian Unity, have surely influenced the social and economic life of the communities of the Kingdom of Sardinia but it did not stop them from protecting their rights and boosted a constant dialogue with the administrative and governmental authorities.

\section{Documentary appendix of some of the documents conserved at the Jewish Archive Terracini of Turin ${ }^{51}$}

1) Purchase of part of the building belonging to Jean Louis Bonello to the Jewish community of Mondovì dating back to 14th January 1807.

AET, Comunità ebraica di Mondovì, Patrimonio, beni immobili. Sinagoga-1807/1913, I.2.2.1

Vente par le sieur Jean Louis Bonello à profit de l'Université des juifs etabli à Mondovì, avec constitution de vente perpetuelle depart de l'université au profit de dit sieur Jean Louis Bonello.

L'an dix-huit-cent-sept, ce quatorze du mois de janvier, en la ville de Mondovì, Département de la Stura, et à la présence des messieurs Joseph Durando avoué, et Amè Prandi candidat avoué tous les deux demeurants en cette ville, témoins connus, et jouissants de droit civils.

Par devant nous Charle François Bassi notaire impérial a la résidence de cette ville est comparu le sieur Thomas Bonello propriétaire, domicilié en la commune de Vico, le quel en la qualité de mandataire de sieur Thomas Bonello fils au défunt Jean Thomas, son père domicilie a la même commune constitué en vertu d'acte du cinq thermidore Martelli notaire, duement enregistré le même jour, l'espediction du quel demeure annexe parmi nos minutes, vend à profit de l'université des juifs établie en la presente ville de Mondovì, pour elle stipulant l'ici présent sieur Samuel Salvador Mommigliano fils au défunt Elias Abraham, membre de la même et demeurant en cette ville d'après l'autorité qui vient de lui être conférée par la dite université en vertu de l'acte de procuration de treize présent mois d'janvier passé par devant au notaire duement enregistré, et qui sera annexé au present acte. le troisième étage ou soit dernier de la maison par le même sieur Bonello, possédée en cette ville, incorporée parmi les autres habites par la juiverie, composé d'une grande chambre servant actuellement de synagogue, deux autres petites chambres contiguës, et une gallérie a l'entrée tenant le même vendeur pour la restante maison, les sieurs prêtre Joseph, et avocat Jaques frères Roberi, et Laurent Bruno, avec tous les droits au même étage, et membres appartenant, et à la charge de la dicte université de contribuer pour un tiers au réparations de chaque espèce du toit, et celle vente moyennant le prix et somme de cinq cent francs, que selon l'intelligence précédée au présent

\footnotetext{
${ }^{51}$ The author of this paper, Ida Ferrero, has also transcribed the included documents.
} 
sera constituée en vente perpétuelle, et ainsi sera tenue la dicte université et pour elle les membres que la composent, et solidairement l'un pour l'autre, au payement des intérêts annuel du dit capitale réglée, et convenu en tant du cinq pour cent, laquelle vente sera rachetable à plaisir de la dicte université, la quelle pour leur eté du dit sieur Bonello affecte, et soumet à l'hypothèque le dict étage qu'elle vient d'acquérir, sur lequel il sera lassible au dit vendeur Bonello de prendre l'inscription pour la conservation du tel droit

Et préalable lecture du présent acte faite au parties en présence des témoins ils ont signé comme à l'original. Tomaso Bonello, Samuel Salvador Momigliano, Joseph Durando Temoin, Amé Prandi témoin avec paraphe Carles François Bassi notaire

Enregistré au bureau de Mondovì le vingtrois janvier 1809 vol. 10 fol. $30 \mathrm{~V}$ cap. 2 et 3 reçu vingt franc signé Magnan

Acte de procuration

L'an dix-huit cent sept, ce treize du mois de janvier, en la commune de Mondovì, departememt de la ', et à la présence des sieurs Joseph Durando avoué, et Amè Prandi candidat avoué tous les deux demeurants en cette ville témoins connus et jouissants de droit civils .

Par devant nous Charles François Bassi notaire imperial à la residence de cette ville sont comparus les membres soussignées composant l'entière université des juifs établie en cette ville, lesquels nomment et constituent pour procureur de la dicte université le sieur Samuel Salvador Momigliano membre de la même université en cette ville, au quel confient l'autorité de faire pour compte de la même l'achat du sieur Jean Louis Bonello de la commune de Vico de la chambre servant actuellement de synagogue, et incorporée en la maison propre du même sieur Bonello, en convenir le prix et le constituer au profit du même en vente perpétuelle, à cet fin soumetre à l'hypothèque les biens de la même université, convenir et stipuler intérêts annuels au taux qui lui convient, promettant la dite université d'avec un tel contrat pour subsistant en tout son entendu, et de le rattifier si le besoins, echetra et préalable lecture su present acte faite avec dits membres soussignees en presence des témoins ils ont signé comme à l'original Donato Levi fu Salvador Sindico, Israel Levi, Israel Samuel Levi, Donato Levi fu Sion Giuseppeanselmo Levi, Michele Levi, Simone Graziadio Momigliano, Samuel Isach Momigliano

seph Durand temoin, Amè Prandi temoin

Avec paraphe Carles Francois Bassi notaire

Enregistré au bureau de Mondovì le treize janvier 1807 vol. 10 fol. $21 \mathrm{~V}$ cat $4^{\circ}$ recu un franc

L'avanti scritto da me ricevuto e registrato in questa città come dalla premessa ricevuto l'ho fatto levare dal sig. Federico Bassi per il sig. Gianluigi Bonello in fede Mondo 
li 10 agosto mille ottocento venti due

Carlo Francesco Bassi

2) Decision of the French Finance Ministry dating back to 18th November 1809 AET, Comunità ebraica di Mondovì, Patrimonio, Beni immobili, Cimitero-1809/1914, IV.1.1

Ministère des finances

\section{1e Division}

Décision du 18 novembre 1809

Les juifs résiliant dans la ville de Mondovì dipt. de la Stura, sont maintenant dans la possession et jouissance du terrain dépendant des fortification de cette ville et servant de cimetière conformément aux dispositions de l'article 9 du Décret Impérial du 23 mai 1809 signé Gandini

Pour l'ampliation

Le Ministre des Finances

Signé le Duc de Gaeta

Per copia conforme

Cuneo il 17 ottobre 1851

Il Segretario Capo dell'Intend. Gen.

G. Sassi

Ricerca L. 1

Copia--------80

Copia--------80

3) Decision of the Administration council of the Jewish community of Mondovi dating back to 20th May 1869

AET, Comunità ebraica di Mondovì, Patrimonio, beni immobili. Sinagoga-1807/1913, affrancamento censo e acquisto, Estinzione del debito dell'oratorio, 1.2.2.5.

Consiglio dell'amministrazione

Israelitica di Mondovì

Avviso e copia di deliberazione

OGGETTO:

Estinzione del debito sull'oratorio

Avendo la nostra comunione acquistato nel gennaio dell'anno 1807 l'attuale sacro oratorio da certo Bonelli ora defunto per la somma di lire cinquecento, col 
carico di un annuo censo di lire 25 fin qui regolarmente pagate ed al presente dovendosi a tenore delle seguenti leggi rinnovare l'Istrumento in proposito cogli eredi del suddetto Bonelli

\section{Il Consiglio d'Amministrazione}

Adunatosi addi 4 del corrente mese di maggio per decidere all'uopo nelle persone dei signori Levi Abram Davide presidente, Levi Beniamino fu Raffael e Levi Israel fu Salvador Issacan Consiglieri con intervento del rabbino infrascritto

\section{Considerando}

Che un censo annuo sovra un Sacro edificio mentre è cosa di poco decoro porta una spesa continua che è bene eliminare dai bilanci e l'edificio stesso non rimanendo mai di assoluta proprietà della Comunione,

Considerando che il creditore deve a nostro vantaggio la somma di L. 50 ove gli venga pagato il debito per intiero

Considerando che senza aggravare per il momento i contribuenti, una delle nostre confraternite religiose può prelevare dai suoi fondi la suddetta somma di L. 450 rimborsabile in tre rate coi dovuti interessi

Si delibera all'unanimità

Di prelevare ad una confraternita la somma di L. 450 da pagarsi agli eredi del defunto Bonelli cancellando così il debito contratto e nello stesso tempo il censo relativo

Di ripartire la stessa somma in tre rate dal L. 150 l'una da aggiungersi nei bilanci degli anni 1870-71 e 72

La presente deliberazione mandata a pubblicare per giorni 8 nell'Oratorio affinchè i contribuenti che avessero qualche cosa in contrario possano fare le loro osservazioni al Consiglio Amministrativo.

Sarà quindi il tutto rassegnato all'approvazione dell'Autorità Governativa a norma della Legge Organica 4 luglio 1857

Pel consiglio d'amministrazione

II segretario

II Presidente

Flaminio Serez

Levi A

Davide

Il presente avviso venne pubblicato alla porta dell'oratorio tutto il tempo voluto dallla legge, ne si ebbero contestazioni od osservazioni di sorta. Si rassegna quindi all'Illustrissimo detto sig. Prefetto la voluta approvazione

Mondovì 19 maggio 1869

Rab Flaminio Serez

Amministrazione Israelitica Mondovì

Visto

Mondovì 20

maggio 1869

II sig. Prefetto 
4) Legal advice of Giovanni Battista Cassinis for the Università Israelitica di Mondovì

AET, Comunità ebraica di Mondovì, Patrimonio, Beni immobili, Cimitero-1809/1914, IV. 1.7.

\section{2 gennaio 1852}

Richiesto a nome dell'Università Israelitica di Mondovì di emettere il mio parere sui seguenti due quesiti

Se essa abbia diritto di rivendicare la pezza n. 16565

Se abbia diritto di esimersi dal pagamento di scudi 15 da lire 3 delle lire 45 per essa corrisposte annualmente e prima dell'occupazione francese e dopo il 1814 al Governo in ricognizione del dominio di dette pezze

Rispondo,

Dai documenti che mi sono stati comunicati si desumerebbe quanto in appresso

Che la predetta Università israelitica prima ancora della decisione del ministro delle finanze del 19 novembre 1809 di cui si parlerà in seguito, si trovava nell'immemoriale possesso delle pezze suddette l'una cioè la pezza 16566 destinata ad uso di cimitero, e la pezza 16565 inserviente di accesso alla prima.

Che anteriormente al Governo francese l'Università pagava alle regie finanze per titolo di ricognizione del diretto dominio di dette pezze un annuo canone di scudi 15.

Che alla sopravvenienza del Governo francese l'Università israelitica di Mondovì non pagò più il mentovato canone, e colla decisione suddetta del Ministro di Finanze venne mantenuta nel possesso e godimento del terreno in discorso, ossia come ivi si legge del terreno dipendente dalle fortificazioni di Mondovì inserviente di cimitero conformemente alle disposizioni di decreto imperiale del 23 maggio 1806

Che cessata l'occupazione francese il Comandante della città di Mondovì richiamò l'antica prestazione dei quindeci scudi, e di più observando, che l'Università Israelitica si servisse di una di dette pezze per cimitero, diede ad un estraneo in locazione unitamente agli spalti della cittadella la pezza descritta col numero 16565

Ciò premesso si appalesa come allo scopo proposto debba I'Università israelitica essere munita di possesso manutenibile o di valido titolo

Procedendo a questa investigazione io credo anzi tutto doversi distinguere la questione che riguarda i terreni da quella che concerne il pagamento del canone.

Discorrerò principalmente del terreno poscia del canone.

In ordine al terreno non parlerò della pezza 16566, inserviente il cimitero, siccome quella, che non solo è posseduta attualmente dall'Università ma intorno a cui non vi ha questione di sorta.

Limitando perciò la discussione alla pezza n.16565, io credo, che l'Università 
non debba appoggiare il suo assunto né nel decreto imperiale 18 maggio 1806 né nell'analoga decisione del Ministro di Finanze del 19 novembre 1809 ma bensì al possesso immemoriale in cui ella si troverebbe della pezza suddetta anteriormente a quell'epoca.

Ove l'Università sia in grado di provare questo suo immemoriale possesso, resta tuttavia a vedersi se non resistano al di lei assunto i dati seguenti

La circostanza che la pezza 16565 non serviva che di accesso alla pezza n. 16566 ossia dii passaggio al cimitero, e che in oggi non abbisognerebbe ella più di tale passaggio

La stessa decisione ministeriale suddetta del 19 novembre 1809, sia per se stessa sia in quanto ne risulterebbe, che quel terreno era di proprietà demaniale, $\mathrm{e}$ quindi secondo le leggi vigenti presso di noi anteriormente ai codici francese, e patrio immune da prescrizione

La circostanza che l'Università oggi non possegga più quella pezza

$\gamma 1$

In ordine alla prima di queste difficoltà io non la vedrei tale da distrurre i diritti dipendenti dal possesso immemoriale che l'Università israelitica fosse in grado di giustiificare.

Difatti qualunque sia l'uso a cui la medesima inservisse resterebbe sempre a carico del governo il demostrare che l'Università israelitica non avesse sulla medesima che una servitù di passaggio ossia che ella esercitasse unicamente quel passaggio a titolo di servitù.

Ma per giungere a questa prova dovrebbe altresì il Governo dimostrare, che nella pezza medesima, e segnatamente nel rimanente terreno latistante a quel passaggio egli esercitasse ragioni di proprietà, quali sarebbero coltivando, concedendo in affitto, e simili. Se egli ciò non provi, e ritenuto che la servitù non si presume, io credo, che quand'anche l'Università non fosse in grado di provare qualche atto di proprietà dal canto suo nelle altre parti del fondo, basterebbe il solo esercizio del passaggio a giustificazione del suo diritto, e possesso a titolo di proprietà.

r 2

La seconda difficoltà può emergere come dissi dalla mentovata decisione ministeriale del 19 novembre 1809.

Invero allo stato delle idee preconcette intorno a questa decisione e secondo le quali come si appalesa dai documenti che mi furono comunicati, questa decisione e l'analogo decreto imperiale in essa rammentato d'invocherebbero come un titolo, può a prima giunta parer singolare che anzi io nela consideri come un elemento di difficoltà, egli è per ciò necessario che anzitutto io dimostri, se da quella decisione possono trarsi validi argomenti a sostegno dell'ascritto dell'Università, essa non può, ne debbe esserne il principale fondamento o per meglio dire il titolo.

Onde questa decisione potesse valere come un titolo, sarebbe necessario che 
fosse un titolo di concessione egli stesso il decreto imperiale mentovato per molto che la decisione in discorso ne fosse l'attuazione.

Ma così non è, e per i seguenti motivi:

Perché quel Decreto imperiale non esiste nella raccolta ufficiale delle leggi del Governo

Perché quand'anche esistesse diffatti, e si potesse in alcuna parte rinvenire, e se ne volessero avere gli effetti d'una vera alienazione a favore dell'Università, esso non sarebbe stato a ciò efficace, imperocché non si sarebbe potuto tale alienazione operare tranne per legge.

Perché stando ai termini della decisione, che dovette necessariamente essere conforme al Decreto, vi si vedrebbe piuttosto accordato il godimento pel fine ivi indicato cioè di uso di cimitero, anziché fatta una vera alienazione.

Quest'ultima considerazione basta a dimostrare come la mentovata decisione potrebbe venire opposta all'Università israelitica come una difficoltà.

Se ne aggiungerebbe un'altra pressoché altronde identica alla prima, ed è che sebbene I'Università israelitica fosse mantenuta nel suo possesso esso dall'un canto si riferirebbe alla sola pezza inserviente di cimitero, e così la pezza 16566, e d'altro canto la si direbbe indipendente dalle fortificazioni della città, il che indicherebbe non solo una proprietà demaniale, ma implicherebbe il concetto di una speciale destinazione di quel terreno, la quale renderebbe assolutamente precaria la concessione di godimento ivi contenuta.

Dimostrato così come non debba, né possa l'Università fare assegnamento sopra quella decisione ministeriale, io passo a dimostrare come non solo non potrebbe esserle opposta come una difficoltà, ma come anzi ne può l'Università ricavare favorevole argomentazione al suo assunto.

Suppongo anzitutto, che l'Università sia in grado di dimostrare l'immemoriale suo possesso; se così è, le espressioni usate in quella decisione non potevano in nessuna guisa distrurre il fatto medesimo ed i legali effetti che ne derivano.

Né giova siavisi detto, che quel terreno era dipendente dalle fortificazioni della città imperocché dato che l'Università israelitica si trovasse munita di antecedente possesso atto a prescrivere, né la concessione in discorso in quanto accenni a semplice godimento, ed alla speciale destinazione di cimitero né quella enunciazione poterono novare la ragione dei diritti, che in effetto all'università stessa appartenessero

In mezzo a ciò non può tuttavia negarsi, che quel terreno era di spettanza dello Stato; ora siccome anteriormente ai codici francesi, e patrio le proprietà demaniali erano presso di noi imprescrittibili, come il sono anche secondo i codici stessi $i$ diritti demaniali contemplati nel libro $2^{\circ}$ cap. $3^{\circ}$ titolo $1^{\circ}$ del codice patrio, tra cui le mura, le fossa, i bastioni delle piazze ed i terreni delle fortificazion ${ }^{52}$, che non sono piazze di guerra, di qui potrebbe arguirsi che quel possesso quand'anche avesse di fatto esistito non fosse attendibile per la prescrizione.

${ }^{52}$ Cod. civ. art. 421-422 
A ciò però potrebbe rispondere nel modo seguente:

le proprietà demaniali erano presso di noi imprescrittibili tuttavolta, che si voleva invocare la prescrizione come mezzo di acquisto indipendentemente da ogni causa che facesse presumere il titolo; ma quando il tempo del possesso era antichissimo, ed accompagnato da circostanze che ne facevano presumere un'origine consensuale, in allora quel possesso riusciva attendibile alla prescrizione, ed effettivamente la produceva.

Così è del terreno stesso delle fortificazioni, e dei bastioni delle piazze che non sono più piazze di guerra; essi ben sono dichiarati di proprietà demaniale , ma alienabili, indi ancora prescrittibili.

Ora siccome il possesso dell'Università israelitica era accompagnato dal pagamento di un canone, aveva perciò un'origine consensuale. Egli era, e fu tale insomma da costituire il fondamento d'unn diritto irrevocabile, semprechè si pagasse il canone consueto.

$\mathrm{Ne}$ fa in contrario, come ben si comprende, che pendente il governo francese non siasi pagato il canone; ciò non tolse l'antica origine, ciò non distrusse quei diritti ingeniti ad un possesso legittimo che già l'Università israelitica ne aveva acquistati.

Col 1814 essendosi poi di nuovo ripristinato il Canone, l'Università israelitica venne reintegrata, se pure ve ne fosse stato il bisogno in tutta quella condizione di diritto, e di fatto, in cui si trovava anteriormente all'occupazione francese.

r3

Più grave di ogni altra vi è la difficoltà che sorge da che l'Università israelitica non possegga più la pezza 16565.

Nel che vuolsi distinguere se da più di 30 anni essa abbia cessato di possederla ovvero da minor tempo.

Avvegnachè nel primo caso essa per difetto così di titolo come di possesso non avrebbe estremo veruno per rivendicarla, le gioverebbe nel secondo caso l'antico possesso, comechè non distrutto ancora da possesso contrario che ne abbia l'azione di rivendicazione.

Passando in ora a ragionare del Canone, già da quanto ho di sovra osservato si apppalesa che non potrebbe scompagnarsi il pagamento del canone dalla ritenzione del terreno.

Questa ritenzione, questo possesso, come dissi di sopra, producono l'utile effetto della prescrizione per ciò appunto che hanno con se una prova del consenso del governo; in altri termini quel possesso, e quel canone costituiscono per così dire un ente solo complessivo, ed inscindibile, talché né potrebbe il governo pretendere il canone senza lasciare all'Università il terreno, né questa ritenere il terreno senza pagare il canone.

Suppongasi pertanto che l'Università non potesse più recuperare la pezza $\mathrm{n}$. 16565; sarebbe una conseguenza dello stesso principio, che dovesse farsi luogo ad una proporzionata diminuzione del canone. 
Dietro a tutte le cose sin qui dette conchiudo:

Che l'Università ha diritto ad entrambe le pezze di terreno summentovate, ove ella sia in grado di giustificare un possesso immemoriale

Che al possesso, e non alla decisione ministeriale, e al decreto imperiale suddetti ella debbe fondare il suo assunto

Che non avrebbe il diritto di rivendicare la pezza n. 16565 ove da più di anni 30 ella abbia cessato di possederla

Che non potrebbe dispensarsi dal pagamento del canone

Che ove ella non potesse più conseguire la pezza n. 16565 ella avrebbe diritto ad una proporzionata diminuzione del canone.

Tale è il mio avviso.

Torino il 12 gennaio 1852

G.B. Cassinis

\section{Bibliography}

Artom E., 1950: Gli ebrei nel Settecento, in "La Rassegna Mensile di Israel", terza serie, 16/1, January 1950, Unione delle Comunitá Ebraiche Italiane, pp. 23-31

Baccelli A., 1892: Brevi note intorno al carattere del «ius gazagà» in Roma, in "La legge. Monitore giudiziario ed amministrativo del Regno d'Italia”, anno XXXII, vol. I

Capefigue B.,1842: L'Europa durante il consolato e l'impero di Napoleone, versione con note ed illustrazioni storiche di Gaetano Barbieri, Napoli, presso Gaetano Nobile tipografo libraio

Cattaneo C., 1860: Memorie di economia pubblica dal 1833 al 1860, Milano, Sanvito

Caesar M., 2019 : Les juifs et le prince: entre législation et conflits de juridiction dans le duché de Savoie à la fin du Moyen Âge, in F. Morenzoni (ed), La loi du prince. La Raccolta normativa sabauda di Amedeo VIII (1430), in collaboration with M. Caesar, I (Deputazione Subalpina di storia patria, Biblioteca storica subalpina, CCXXVIII), Torino, Deputazione Subalpina di storia patria, pp. 357374

Colorni V., 1946: L'eguaglianza come limite della legge nel diritto intermedio e moderno, Milano, Giuffré

Colorni Vittore, 1956: Gli Ebrei nel sistema del diritto comune fino alla prima emancipazione, Milano, Giuffré

Cracco Ruggini L., 1964: Note sugli ebrei in Italia dal IV al XVI secolo, in "Rivista storica italiana", LXXIV

Della Peruta F., 1997: Gli ebrei nel Risorgimento fra interdizioni ed emancipazione, in C. Vivanti (ed), Storia d'Italia, Annali. II, Gli ebrei in Italia, vol. II, Torino, 
Einaudi editore, pp. 1133-1167

Dionisotti C., 1881: Storia della magistratura Piemontese, vol. I, Torino, Roux e Favale

Di Rienzo E., 1994: Tra discriminazione, assimilazione ed emancipazione: la questione ebraica in Francia tra Rivoluzione ed impero, in P. Alatri, S. Grassi (eds), La questione ebraica dall'llluminismo all'Impero, 1700-1815: atti del convegno della Società italiana di studi sul secolo 18 , Napoli, Edizioni Scientifiche editore, pp. 87-105

Duboin F.A., 1825: Raccolta per ordine di materie delle leggi, provvidenze edittti, manifesti ecc. pubblicati dal principio dell'anno 1681 sino agli 8 dicembre 1798 sotto il felicissimo dominio della Real casa di Savoia per servire di continuazione a quella del senatore Borrelli, vol. II, Torino, dai tipi degli editori Davico e Picco

Echevarria A., Monferrer-Sala J.P., Tolan J. (eds), 2016: Law and religious minorities in medieval societies: between theory and praxis, Turnhout, Brepols

Foa A., 1999: Ebrei in Europa. Dalla Peste Nera all'emancipazione XIVXIX secolo, Bari-Roma, Editori Laterza

Gambini F., 1834: Della cittadinanza giudaica in Europa: problema di Francesco Gambini astigiano, Torino, Tipografia Pomba

Garizio E., 1867: Iscrizioni ed elogio funebre nelle solenni esequie fatte a Giambattista Cassinis dal Municipio di Masserano il 19 febbr. 1867, Torino, tip. Bellardi, Appiotti e Giorsini

Haverkamp A., 2004: The Jews of Europe in the Middle Ages; by way of introduction, in C. Cluse (ed), The Jews of Europe in the Middle Ages, tenth to fifteenth centuries, Proceedings of the international Symposium held at Speyer, 20-25 October 2002, Turnhout, pp. 1-16

Laras G.,1968: Intorno al "ius cazacà» nella storia del ghetto di Ancona, in "Quaderni storici delle Marche", 3/7 January 1968, pp. 27-55

Lazare B., 2006: L'antisemitismo la sua storia e le sue cause, Matera, Altrimedia Edizioni

Levi G., 1952: Sulle premesse social - economiche dell'emancipazione degli Ebrei nel Regno di Sardegna, in "La Rassegna Mensile di Israel", third series, vol. 18, n. 10, Unione delle Comunitá Ebraiche Italiane, pp. 412-437

Luzzatto A., 1977: L'insediamento degli ebrei in Piemonte durante il secolo XV, in "La Rassegna Mensile di Israel”, terza serie, 43/5-6, maggio-giugno 1977, pp. 279-292

Mantelli C., 1843: Giurisprudenza del codice civile e delle altre leggi dei Regi Stati ossia collezione metodica e progressiva delle decisioni e sentenze, vol. VII, Alessandria, presso Luigi Guidetti tipografo librajo

Martone L., 1978: voce Giovanni Battista Cassinis, in Dizionario Biografico degli 
Italiani, vol. 21, Roma, Istituto della Enciclopedia Italiana, pp. 490-494

Maternini Zotta M.F, 1994: La condizione giuridica delle comunità ebraiche italiane nel secolo XVIII, in P. Alatri, S. Grassi (eds), La questione ebraica dall'Illuminismo all'Impero, 1700-1815: atti del convegno della Società italiana di studi sul secolo 18\%, Napoli, pp. 235-236

Merlin P.A.,1836: Dizionario universale ossia repertorio ragionato di giurisprudenza e questioni di diritto di Merlin, antico procuratore generale presso la Corte di Cassazione in Francia, versione italiana di una società di avvocati sotto la direzione dell'avvocato Filippo Carillo, Venezia, Antonelli

Montalcini C.,1884: Vicende delle pubbliche libertà in Piemonte dai primi tempi di casa Savoia ad Emanuele Filiberto, Torino, Tipografia A. Locatelli

Raccolta di costituzioni pontificie sentenze, decisioni, voti e pareri concernenti il gius di gazagà degli israeliti sulle case del già ghetto di Roma, 1877, Roma, Tipografia fratelli Pallotta

Sarti T., 1896: II Parlamento subalpino e nazionale, Terni, Tipografia Pintucci

Solimano S., 2003: Il letto di Procuste. Diritto e politica nella formazione del Codice civile unitario. I progetti Cassinis (1860-1861), (Università degli Studi di Milano, Facoltà di Giurisprudenza, pubblicazioni dell'Istituto di Storia del diritto medievale e moderno, 30), Milano, Giuffré editore

Tama D. (ed.), 1807 : Collection des procès-verbaux et décisions du Grand Sanhédrin, Paris, l'éditeur Treuttel et Wûrtz

Vigna L.-Aliberti V., 1848: Della condizione attuale degli ebrei in Piemonte. Estratto dal dizionario di diritto amministrativo, Torino,Tipografia Favale 